\title{
EFFECT OF DIFFERENT LEVELS OF SOAKED-WATER BARLEY AND FABA BEAN (MINOR) AS A PARTIAL SUBSTITUTE FOR MAIZE AND SOYBEANS IN GROWTH AND PRODUCTION OF QUAIL'S DIETS
}

Samir Hameed Majeed

Malik Mohamad Shukri
Firas Khalil Ibrahim

Salim thanon younis

Nenavah Research Department - Office of Agricultural Reasearch

Email: firas_kahli1@yahoo.com

\begin{abstract}
The study was carried out in the Poultry farms/ Nineveh Research Department, by using 756 unsexing quail birds two weeks aged, distributed into nine experimental treatments with 3 replicates per treatment, each contained 28 birds, primary live weight $63.8 \mathrm{~g}$, birds was fed on growth and production diets depending on growth stage. Results showed a significant improvement $(\mathrm{P} \leq 0.05)$ for soakedwater barley (SWB) treatments $10 \%$ and $20 \%$ on weight gain g/ bird (WG) and feed conversion ratio (FCR), FCR g food/g egg, egg production\% for first four weeks of production, hatching $\%$ from total eggs for the first four, second and third weeks of production. Mathematic difference showed for the rest of the traits. The levels of Faba Bean (FB) FB minor $10 \%$ and $20 \%$ had a negative and significant effect $(\mathrm{P} \leq$ $0,05)$ on the WG and FCR at 3-5 weeks age, FCR for the first four weeks of production and eggs production \%, a positive improvement $(\mathrm{P} \leq 0.05)$ for FCR and egg production $\%$ for third four weeks of production.

Key words: soaked water barley, Faba bean (minor), quail production
\end{abstract}

Received:18/2/2019, Accepted: 3/9/2019

\section{INTRODUCTION}

Quail has characteristics that make it preferred among breeding animals due to its small size, rapid growth, resistance to many common broiler chickens diseases, high meat quality, high product prices, low nutrition and treatment costs, and rapid return of capital, so it is currently being raised in many countries (Mortazavi and Afsharmanesh, 2017). Nutrition is the largest part of total costs in poultry industry, so early thought of finding alternatives to feed, especially protein sources and lowest costs without causing any negative effects in production performance of birds (Abdel-Abbas and Al-Majma'i, 2007).

Barley (Hordeum vuglare) is a source of energy with limited used in poultry feed because it contains a high proportion of non-starch polysaccharides, especially $\beta$-glucan, which reduces feed utilization and thus reduces production (Ahmad, 2011) by reducing the digestibility of starches by blocking digestive enzymes from reaching starch granulars during digestion (Senkoylu et al. 2004). Therefore, viscosity increases the gastrointestinal bird's tract and reduces nutrients speed passage and absorption in intestines, thus reducing the consumption of diet (AlKaisey et al., 2007), barley is a good alternative to corn in the diets (Kianfar et al., 2013). There are several ways to improve barley nutritional value as soaked in water, which positively affects its nutritional value by increasing the effectiveness 
of $\beta$-glucanase enzyme and thus reducing the viscosity of barley (Svihus et al., 1997).

Soybeans are important sources of protein in poultry diets but are often very expensive, so researchers have found alternatives to local that can be partially or entirely replaced (Koivunen et al.,2014). Faba bean (Vicia Faba Var, Minor) is relatively high in protein (up to $26 \%$ ), starch (30\%) and a good source of lysine, the presence of some anti-nutrient factors (ANF) such as Vicine, Covicine and the low content of sulfuric acid, methionine and systeine decreasing the use in poultry diets (Abdel-Abbas and Areaaer, 2014; Bosco et al.,2013). Feeding broiler chickens on diets containing SWB resulted a significant effect on final live weight (Ahmad, 2011), similarly, treated barley (fermentation or germination) resulted an improvement in the body weight in quail (Kianfar et al.,2013). Replacing FB minor FB minor (100\% soy bean allowance) give insignificant lowest live weight in the 6 week old for broiler (Abdel-Abbas, and Al-Majma'i, 2007). A higher WG was obtained in broiler chickens when feeding on a diet containing SWB compared to other treatments (Ahmed, 2011). Barley treatment by heat resulted an improvement in the weight gain of broiler for 1-7 days age (Garci'a et al.,2008).

The replaced FB minor (100\% soy bean substitutes) also resulted an improvement in WG in broiler at 8 weeks age and during the cumulative period 2-8 weeks (Abdel-Abbas and Al-Majma'i, 2007). treated barley increased and improved FC by heating (Garci'a et al., 2008) at 1-7 days broiler age, soaked water (Ahmad , 2011) in broiler, (fermentation or germination) in quail (Kianfar et al.,2013) and germinating (Rasteh et al., 2016) in hens layer, while the use of FB minor $100 \%$ substitutes for soybean resulted in lower FC compared with the rest of the treatments (Abdel-Abbas and Al-Mogama'i, 2007), on the other hand there are no significant affected for the use of FB minor in broiler FC (Koivunen et al., 2014). SWB has a positive and significant effect $(\mathrm{P} \leq 0.05)$ on this trait (Ahmad, 2011). when treated (fermentation or germination) decreased FCR (Kianfar et al., 2013), increasing germinated barley in diet has improved FCR (Rasteh et al., 2016). FCR was not affected by using minor, neither in broilers at 6 weeks of age (Abdel-Abbas and Al-Mogama'i, 2007) nor in hen layer (Koivunen et al., 2014). Used of germinated barley has a significant increased on EP\% in hen layer (Rasteh et al., 2016), While the use of FB minor did not have an effect on same trait (Koivunen et al., 2014).

\section{MATERIALS AND METHODS}

The study was carried out in the Poultry farms /Nineveh Research Department, using 756 unsexing quail birds, two weeks age, distributed on nine experimental treatments, 3 replicates /treatment, each containing 28 birds, the initial weight $63.8 \mathrm{~g}$ live weight, the experimental growth diets (Table 1) were given at the beginning of third week of age to the end of fifth week, then replaced by the production diets (Table 2).

Barley treatment: black barley use from the local market, soaking in water (2 liters of water : per $1 \mathrm{~kg}$ barley) for 24 hours at room temperature, 
Table (1): Experimental growth quail diets from third week of age to the end of fifth week.

\begin{tabular}{|c|c|c|c|c|c|c|c|c|c|}
\hline \multirow{2}{*}{ Ingredients } & 1 & 2 & 3 & 4 & 5 & 6 & 7 & 8 & 9 \\
\hline & $\begin{array}{l}0 \mathrm{SB} \\
0 \mathrm{FB}\end{array}$ & $\begin{array}{l}0 \mathrm{SB} \\
10 \mathrm{FB}\end{array}$ & $\begin{array}{ll}0 \mathrm{SB} \\
20 \mathrm{FB}\end{array}$ & $\begin{array}{l}10 \mathrm{SB} \\
0 \mathrm{FB}\end{array}$ & $\begin{array}{l}20 \mathrm{SB} \\
0 \mathrm{FB}\end{array}$ & $\begin{array}{l}10 \mathrm{SB} \\
10 \mathrm{FB}\end{array}$ & $\begin{array}{l}20 \mathrm{SB} \\
20 \mathrm{FB}\end{array}$ & $\begin{array}{l}10 \mathrm{SB} \\
20 \mathrm{FB}\end{array}$ & $\begin{array}{l}20 \mathrm{SB} \\
10 \mathrm{FB}\end{array}$ \\
\hline yellow corn & 50 & 50 & 50 & 45 & 40 & 45 & 40 & 45 & 40 \\
\hline Barley & 0 & 0 & 0 & 5.9 & 11.8 & 5.9 & 11.8 & 5.9 & 11.8 \\
\hline Wheat & 8 & 8 & 5.2 & 7 & 6.45 & 6.5 & 2 & 4.5 & 3.5 \\
\hline Soybeans & 30 & 27 & 24 & 30 & 30 & 27 & 24 & 24 & 27 \\
\hline FB (Minor) & $\overline{0}$ & 4.2 & 8.4 & $\overline{0}$ & $\overline{0}$ & 4.2 & $\overline{8.4}$ & 8.4 & 4.2 \\
\hline Protein & 5 & 4 & 5 & 5 & 5 & 4 & 5 & 5 & 5.5 \\
\hline Yeast & 2 & 2 & 2.5 & 1.35 & $\overline{1}$ & 2 & 2.3 & 2 & 2 \\
\hline Premix & 1 & 1 & 1 & 1 & 1 & 1 & 1 & 1 & 1 \\
\hline Oil & 2 & 1.8 & 1.9 & 2.5 & 2.75 & 2.4 & 3.5 & 2.2 & 3 \\
\hline Limestone & 2 & 2 & 2 & 2 & 2 & 2 & 2 & 2 & 2 \\
\hline \multicolumn{10}{|l|}{ Chemical analysis } \\
\hline M. E. & 2903 & 2910 & 2916 & 2904 & 2902 & 2918 & 2900 & 2911 & 2916 \\
\hline Crud protein & 21 & 21 & 21 & 21 & 21 & 21 & 21 & 21 & 21 \\
\hline Energy / Protein & 135 & 138 & 137 & 137 & 137 & 138 & 139 & 137 & 136 \\
\hline
\end{tabular}

$\mathrm{SB}=\mathrm{SWB}=$ Soaked Water Barley, FB minor $=$ Faba Bean $($ Minor $)$.

Then dried using sunlight (Ahmad, 2011) indirect for three days, then grind and use in the composition of the diets, the values of the nutrients were calculated for each treatment. The FB minor that was obtained from Agricultural Crops Division/ Nineveh Research Department, was grinded and used in the composition of diets according to experimental treatments. The ratio of barley and FB minor in treatments were as follows:

$1^{\text {st }}$ treatment: 0\%SWB - 0\% FB minor

$2^{\text {nd }}$ treatment: $0 \% \mathrm{SWB}-10 \% \mathrm{FB}$ minor

$3^{\text {rd }}$ treatment: $0 \%$ SWB $-20 \%$ FB minor ${ }^{(2)}$.

$4^{\text {th }}$ treatment: $10 \% \mathrm{SWB}^{(3)}-0 \% \mathrm{FB}$ minor

$5^{\text {th }}$ treatment: $20 \% \mathrm{SWB}^{(4)}-0 \% \mathrm{FB}$ minor

$6^{\text {th }}$ treatment: $10 \%$ SWB $-10 \%$ FB minor

$7^{\text {th }}$ treatment: $20 \%$ SWB $-20 \%$ FB minor

$8^{\text {th }}$ treatment: $10 \%$ SWB $-20 \%$ FB minor

$9^{\text {th }}$ treatment: $20 \% \mathrm{SWB}-10 \% \mathrm{FB}$ minor

(1) Calculated $10 \%$ of soy protein, substituted for $4.2 \%$ FB minor of the total diet (31.8\% crude protein and $2700 \mathrm{kcal}$ representative energy).

( ${ }^{2}$ ) Calculated $20 \%$ of soy protein, substituted for $8.4 \%$ FB minor of the total diet (31.8\% crude protein and $2700 \mathrm{kcal}$ representative energy).

$\left({ }^{3}\right)$ Calculated $20 \%$ of the corn energy replaced with barley energy, which represents $11.8 \%$ barley of the total bush ( $10.7 \%$ crude protein and $28820 \mathrm{kcal}$ representative energy).

$\left({ }^{4}\right)$ Calculated $10 \%$ of the corn energy replaced with barley energy, which represents $5.9 \%$ barley of the total bush ( $10.7 \%$ crude protein and $28820 \mathrm{kcal}$ representative energy) 
Birds were sexed and the excess male were isolated. WG / bird, FC and FCR $\mathrm{g}$ food /g weight were studied at fifth weeks age. On the other hand food FCR $\mathrm{g}$ food/g eggs, EP\%, fertilized eggs\%, and hatching of total eggs\% were studied for the 1st four, $2^{\text {nd }}$ and $3^{\text {rd }}$ weeks of production.

Statistical Analysis: Experimental data was analyzed by factorial Randomized Complete Design (C.R.D) with two factors SWB and FB minor $(3 \times 3)$, to find out the effects of factors and their interactions on the studied traits, the means were compared by using the Duncan test (Al-Rawi and Khalaf Allah, 2000) using statistical program (SAS, 2000).

Table (2): Experimental Production quail diets from the beginning of six week to the end of the experiment.

\begin{tabular}{|c|c|c|c|c|c|c|c|c|c|}
\hline \multirow{2}{*}{ Ingredients } & 1 & 2 & 3 & 4 & 5 & 6 & 7 & 8 & 9 \\
\hline & $\begin{array}{l}0 \mathrm{SB} \\
0 \mathrm{FB}\end{array}$ & $\begin{array}{ll}0 & \mathrm{SB} \\
10 & \mathrm{FB} \\
\end{array}$ & $\begin{array}{ll}0 & \text { SB } \\
20 & \text { FB } \\
\end{array}$ & $\begin{array}{ll}10 & \mathrm{SB} \\
0 & \mathrm{FB}\end{array}$ & $\begin{array}{ll}20 & \mathrm{SB} \\
0 & \mathrm{FB}\end{array}$ & $\begin{array}{l}10 \mathrm{SB} \\
10 \mathrm{FB}\end{array}$ & $\begin{array}{l}20 \mathrm{SB} \\
20 \mathrm{FB}\end{array}$ & $\begin{array}{l}10 \mathrm{SB} \\
20 \mathrm{FB}\end{array}$ & $\begin{array}{l}20 \mathrm{SB} \\
10 \mathrm{FB}\end{array}$ \\
\hline yellow corn & 45 & 45 & 45 & 40.5 & 36 & 40.5 & 36 & 40.5 & 36 \\
\hline Barley & 0 & 0 & 0 & 5.3 & 10.6 & 5.3 & 10.6 & 5.3 & 10.6 \\
\hline Wheat bran & 6 & 6 & 5.5 & 4.7 & 5 & 5 & 4.4 & 5 & 4.5 \\
\hline Wheat & 12.75 & 12 & 11.3 & 13.5 & 12 & 12 & 10 & 11 & 10 \\
\hline Soybeans & 26 & 23.4 & 20.8 & 26 & 26 & 23.4 & 20.8 & 20.8 & 23.4 \\
\hline FB & 0 & 3.7 & 7.4 & 0 & 0 & 3.7 & 7.4 & 7.4 & 3.7 \\
\hline Protein & 1.75 & 3 & 2.5 & 2 & 2 & 2 & 2.7 & 2.5 & 2.5 \\
\hline Yeast & 0.75 & 0.5 & 0.7 & 0.5 & 0.5 & 0.5 & 0.5 & 0.5 & 0.5 \\
\hline Premix & 1 & 1 & 1 & 1 & 1 & 1 & 1 & 1 & 1 \\
\hline cooking oil & 4.25 & 2.9 & 2.8 & 3.5 & 3.9 & 3.6 & 3.6 & 3 & 4 \\
\hline Limestone & 3 & 3 & 3 & 3 & 3 & 3 & 3 & 3 & 3.8 \\
\hline \multicolumn{10}{|c|}{ Chemical analysis } \\
\hline M. E. & 2899 & 2903 & 2901 & 2913 & 2908 & 2925 & 2914 & 2896 & 2904 \\
\hline Crud protein & 19 & 19 & 19 & 19 & 19 & 19 & 19 & 19 & 19 \\
\hline Energy /Protein & 153 & 150 & 152 & 153 & 152 & 154 & 153 & 152 & 153 \\
\hline
\end{tabular}

$\mathrm{SB}=\mathrm{SWB}=$ Soaked Water Barley, FB minor $=$ Faba Bean (Minor).

\section{RESULTS}

Results in table (3) showed a significant effect $(\mathrm{P} \leq 0.05)$ of WSB $10 \%$ and $20 \%$ 101.20 and 100.54 compression to control treatment $85.80 \mathrm{~g} / \mathrm{bird}$. While a significant $(\mathrm{P} \leq 0.05)$ decreasing $\mathrm{WG}$ for $\mathrm{FB}$ minor $10 \%$ and $20 \% 98.83$ and 88.06 comparing with control $100.47 \mathrm{~g} / \mathrm{bird}$. The lowest significant $(\mathrm{P} \leq 0.05) \mathrm{WG}$ for (20\%SWB-0\% FB minor) interaction $62.34 \mathrm{~g} / \mathrm{bird}$, where is the highest WG for (20\%SWB-0\% FB minor) $102.38 \mathrm{~g} / \mathrm{bird}$. Generally the increasing in SWB concentration led to significant $(\mathrm{P} \leq 0.05)$ improving in $\mathrm{WG}$, despite the existence of the FB minor. Table (3) showed no significant differences between the control and SWB treatments $10 \%$ and $20 \%(381.90,384.14$ and 384.79) g / bird, respectively. Also there are no significant differences between control and FB minor $10 \%$ and $20 \%, 380.61,380.96$ and 389.43, respectively, FC increased with the increasing of SWB and FB minor concentration in interaction. SWB treatments have a significant 
superior $(\mathrm{P} \leq 0.05)$ on control, this trail improved by using SWB 3.69 and 3.83 while 4.67 for control. Whereas the FB minor treatments $10 \%$ and $20 \%$ led to increase FCR value with significant $(\mathrm{P} \leq 0.05)$ differences with control means $(3.68,3.86$ and 4.65). The best interaction results are (10\% SWB with $10 \%$ and $20 \% \mathrm{FB}$ minor) which had a significant differences $(\mathrm{P} \leq 0.05)$ with control treatment.

Table (4) showed a significant improved $(\mathrm{P} \leq 0.05)$ for SWB treatments $10 \%$ and $20 \% 4.54$ and 4.57 compared to control treatment 4.96. whereas 20\% FB minor minor treatment 4.98 had a significant difference $(\mathrm{P} \leq 0.05)$ with control 4.57. The only significant difference $(\mathrm{P} \leq 0.05)$ appeared between 0\%SWB -20\% FB minor 6.03 with other interactions and control 4.72. The reason for the high value of FCR may due to ANF in FB minor, so, the bird will try to meet its dietary requirements by increasing the amount of feed consumed. The $2^{\text {nd }}$ four weeks of egg production, no significant effect appeared for SWB treatments 10\% and 20\% compared the control treatment, but simple mathematic increase note with the increasing of SWB 3.74 and $3.76 \mathrm{~g}$ food $/ \mathrm{g}$ egg. A significant decrease $(\mathrm{P} \leq 0.05)$ was found for $20 \%$ FB minor treatment. The interaction between SWB and FB minor levels showed a significant differences $(\mathrm{P} \leq 0.05)$ between $(0 \% \mathrm{SWB}-20 \% \mathrm{FB}$ minor) which had less mean $3.05 \mathrm{~g}$ food/g egg compared with (10\% SWB-0\% FB minor), (20\% SWB $-0 \%$ FB minor) and control. The results of FCR for the $3^{\text {rd }}$ four weeks of egg production showed in the same table, SWB treatments had no significant affect on this trait, whereas FB minor treatments had a significant improvement $(\mathrm{P} \leq 0.05)$, the best significant results for interaction was (0\% SWB - 20\% FB minor) $2.61 \mathrm{~g}$ food / g egg compared to the control treatment.

Table (5) showed a significant superior $(\mathrm{P} \leq 0.05)$ for SWB treatments $10 \%$ and $20 \%$ to control $(63.15 \%, 62.48 \%$ and $55.34 \%)$, FB minor had a significant $(\mathrm{P} \leq$ 0.05 ) decreased for $20 \% \mathrm{FB}$ minor treatment $54.97 \%$ compared to $10 \%$ FB minor and control $61.52 \%$ and $64.48 \%$ respectively, mathematical improved can note for $10 \%$ FB minor to control. There are significant differences and improvement $(\mathrm{P} \leq 0.05)$ for $(10 \% \mathrm{SWB}-0 \% \mathrm{FB}$ minor) $66.58 \%$ and $(0 \% \mathrm{SWB}-10 \% \mathrm{FB}$ minor) $67.43 \%$ compared to control $56.87 \%$ on the other hand a significant decreased $(\mathrm{P} \leq$ $0.05)$ was found for (0\% SWB - 20\% FB minor) $41.73 \%$ compared to control. Same table showed no significant differences between SWB 10\% and 20\% and control $(81.93,81.38$ and 78.03$) \%$ for egg production $\%$ in the $2^{\text {nd }}$ four weeks of production, also, FB minor $10 \%$ and $20 \%$ compared to control $(81.37,81.16$ and $78) \%$ had the same effect. Same results were appeared in interaction that is mean no significant differences appeared between them. At the $3^{\text {rd }}$ four weeks of egg production a significant differences $(\mathrm{P} \leq 0.05)$ appeared between $20 \%$ SWB $91.53 \%$ and $10 \%$ SWB $81.18 \%$ and control $86.48 \%$, as well a significant $(\mathrm{P} \leq 0.05)$ superior for FB minor treatments $10 \%(88.03 \%)$ and $20 \%$ (88.48\%) compared to control $(82.62 \%)$. A significant differences $(\mathrm{P} \leq 0.05)$ between control and interactions treatments $20 \%$ SWB $-10 \%$ FB minor and $20 \%$ SWB $-20 \%$ FB.

No significant differences appeared for SWB, FB minor and their interactions treatments on this trait at $1^{\text {st }}$ four weeks as shown in (table 6) mathematic decreased found with increasing FB minor concentration. At $2^{\text {nd }}$ four weeks of production SWB 20\% significant decreased compared to control (91.47\% and 95.52\%), also no significant differences were shown between FB minor treatments to control, a 
mathematic reduced can note with increasing SWB and FB minor concentrations. Only significant differences between $20 \%$ SWB - 20\% FB minor $88.28 \%$ to other interactions and control. $3^{\text {rd }}$ four weeks of production a mathematic improved found with increasing concentration SWB and reduced with increasing FB minor treatments with no significant differences to control treatments. Lest significant differences $(\mathrm{P} \leq 0.05)$ between $10 \% \mathrm{SWB}-10 \% \mathrm{FB}$ minor to other interactions and control treatments.

$1^{\text {st }}$ four weeks results in table (7) showed a significant increased $10 \%$ SWB to control $61.13 \%$ and $50.93 \%$, no significant effect for FB minor treatments on this trait but a mathematic reduced appeared with increasing FB minor concentration. The highest significant interaction to control for SWB 20\%-0\% FB minor 67.78 . At $2^{\text {nd }}$ four weeks of production SWB $10 \%(85.03 \%)$ had a significant differences $(\mathrm{P} \leq 0.05)$ to SWB $20 \%(78.60 \%)$ and mathematic improved to control treatment $(80.72 \%)$. The Hatch\% reduced with increasing FB minor concentrations with no significant effect, interactions treatments between SWB and FB minor the significant difference $(\mathrm{P} \leq 0.05)$ was shown between $(20 \%$ SWB - 20\% FB minor) $74.03 \%$ and control $86.10 \%$, (10\% SWB - 0\% FB minor) $86.50 \%$ and $(10 \%$ SWB $20 \%$ FB minor) $86.53 \%$. at $3^{\text {rd }}$ four weeks of production SWB $10 \%$ and $20 \%$ improved the hatch\% $75.28 \%$ and $77.97 \%$ the significant difference between control and $20 \%$ SWB only, FB minor treatments had a negative and insignificant effect on the hatch\% which reduced with increasing FB minor concentration compared to control $76.82 \%, 74.78 \%$ and $71.88 \%$. Best results of interaction were $83.18 \%$ for $(20 \%$ SWB - $20 \%$ FB minor $)$ which significant superior $(\mathrm{P} \leq 0.05)$ on control $70.70 \%$ and $(0 \%$ SWB - $20 \%$ FB minor) $63.48 \%$ which is the least value.

\section{DISCUSSION}

Results showed a significant WG for $10 \%$ and $20 \%$ SWB compared to control, this agree with (Svihus et al., 1997; Abdel-Abbas; and Al-Mogama'i, 2007; Garci'a et al., 2008 and Ahmed, 2011) in broiler, while the use of FB minor resulted in a significant decrease in weight gain which disagree with (Abdel-Abbas and Al-Mogama'i, 2007). Results showed no significant differences between the SWB, $10 \%$ and $20 \%$ and control, this results agree with (Garci'a et al., 2008 and Ahmed, 2011) in broilers and (Rasteh et al., 2016) in hens. Also, the levels of FB minor $10 \%$ and $20 \%$ had no significant effect on feed consumed which agree with (Koivunen et al., 2014) in hens, who suggested that the hens needed to consume more feed to meet their nutrient requirements when FB minor is included in the diet. SWB 10\% and 20\% superior to control this results agree with (Ahmed, 2011 and Kianfar et al., 2013), disagree with (Ratesh et al., 2016). use of FB minor 10\% and 20\% led to a significant increase in the efficiency of feed conversion compared to control treatment. In addition, the efficiency of feed conversion based on egg production has improved this status by increasing the concentrations of SWB, and this value has improved overall by increasing the concentration of FB. In general, the percentage of eggs production four three production stages were improved significantly and mathematically by using (20\%) SWB compared to control treatment. Whereas (20\%) FB minor improved this trait at last two of production. Results of the statistical analysis showed increase in this trait using SWB $10 \%$ and $20 \%$ compared to control treatment for first and third periods only. As for effect of $\mathrm{FB}$, it is noticed that the percentage of egg production is improved by increasing the concentration FB minor for three production periods. \%: SWB 
(10\%) improved the first and second production periods, while in the $3^{\text {rd }}$ period both $10 \%$ and 20\% SWB improved Hatched\%, FB minor $10 \%$ and $20 \%$ treatments decreased Hatched\%. Improving eggs quality of current study agree with (Rasteh et al., 2016) in hen and with (Koivunen et al.,2014) for FB minor negative results on eggs quality in hen.

The positive performance of poultry fed diet containing treated barley may be attributed to melting of $\beta$-glucan in water, or to activate internal enzymes in the grains that lead to the destruction $\beta$-glucan (Jacob and Pescatore, 2012), solubility of $\beta$-glucan leads to reducing viscosity. WG, feed consumption and feed conversion have a close relationship with the viscosity which is an important indicator of nutritional value of barley in poultry feed (Svihus et al.,1997; Ahmad, 2011 and Kianfar et al.,2013). Decreased performance in poultry fed FB minor is due to some antiviral compounds in FB, or may be due to lower amino acid methionine and systeine, Decrease egg production with increase in concentration of FB minor, may be due to containing Vicin compounds erythrocyte hemolysis, or, Vicin compounds may reduce the amount of raw material available to the granules and thus destroy them or destroy the ovaries (Koivunen et al.,2014). 
Mesopotamia J. of Agric.

Vol. (47) No. (2) 2019
ISSN: 2224 - 9796 (Online)

ISSN: 1815 - 316 X (Print)

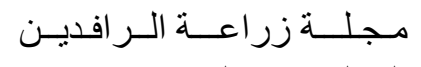

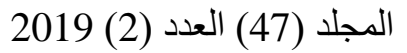

Table (3): Effect of SWB and FB minor on weight gain, feed consumed and feed conversion ratio at 3-5 weeks age of quail.

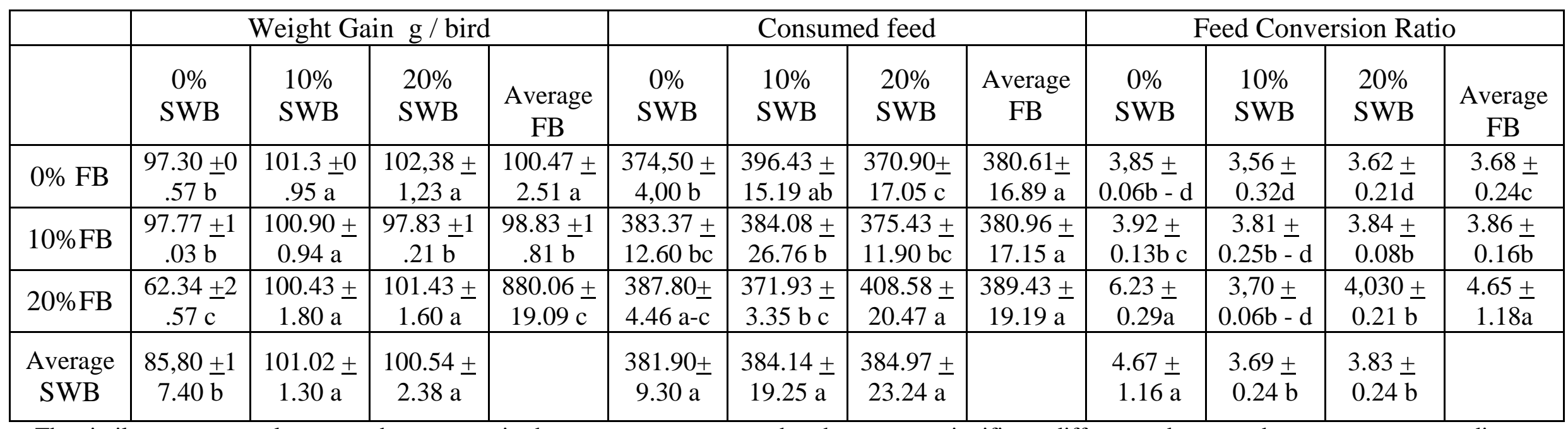

The similar or common letters on the averages in the same category mean that there are no significant differences between these averages , according to the Duncan test.

The different letters on the averages within the same character have significant differences $(\mathrm{P} \leq 0.05)$ among those averages, according to the Duncan test 
Mesopotamia J. of Agric.

Vol. (47) No. (2) 2019
ISSN: 2224 - 9796 (Online)

ISSN: 1815 - 316 X (Print)

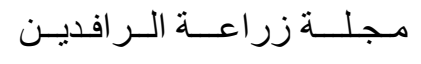

المجلد (47) العدد (2) 2019

Table (4): Effect of SWB and FB minor treatments on feed conversion ratio $\mathrm{g}$ feed $/ \mathrm{g}$ egg at $1^{\text {st }}, 2^{\text {nd }}$ and $3^{\text {rd }}$ four weeks of production.

\begin{tabular}{|c|c|c|c|c|c|c|c|c|c|c|c|c|}
\hline & \multicolumn{4}{|c|}{$1-4$ weeks } & \multicolumn{4}{|c|}{5 - 8 weeks } & \multicolumn{4}{|c|}{$9-12$ weeks } \\
\hline & $\begin{array}{c}0 \% \\
\text { SWB }\end{array}$ & $\begin{array}{l}10 \% \\
\text { SWB }\end{array}$ & $\begin{array}{c}20 \% \\
\text { SWB }\end{array}$ & $\begin{array}{c}\text { Average } \\
\text { FB }\end{array}$ & $\begin{array}{c}0 \% \\
\text { SWB }\end{array}$ & $\begin{array}{l}10 \% \\
\text { SWB }\end{array}$ & $\begin{array}{l}20 \% \\
\text { SWB }\end{array}$ & $\begin{array}{c}\text { Average } \\
\text { FB }\end{array}$ & $\begin{array}{c}0 \% \\
\text { SWB }\end{array}$ & $\begin{array}{l}10 \% \\
\text { SWB }\end{array}$ & $\begin{array}{l}20 \% \\
\text { SWB }\end{array}$ & $\begin{array}{c}\text { Average } \\
\text { FB }\end{array}$ \\
\hline $0 \% \mathrm{FB}$ & $\begin{array}{l}4.72 \pm \\
0.04 \mathrm{~b}\end{array}$ & $\begin{array}{l}4.41 \pm \\
0.21 \mathrm{~b}\end{array}$ & $\begin{array}{l}4,58 \pm \\
0.49 \mathrm{~b}\end{array}$ & $\begin{array}{l}4,57 \pm \\
0.31 \mathrm{~b}\end{array}$ & $\begin{array}{c}3.79 \pm \\
0.18 \mathrm{a}-\mathrm{c}\end{array}$ & $\begin{array}{c}3.87 \pm \\
0.50 \mathrm{a}-\mathrm{c}\end{array}$ & $\begin{array}{l}4.27 \pm \\
0.54 \mathrm{a}\end{array}$ & $\begin{array}{l}3.98 \pm \\
0.45 \mathrm{a}\end{array}$ & $\begin{array}{c}3.21 \pm \\
0.08 \mathrm{a}-\mathrm{c}\end{array}$ & $\begin{array}{r}3,56 \pm \\
0,28 \mathrm{a}\end{array}$ & $\begin{array}{l}3.30 \pm \\
0.27 \mathrm{ab}\end{array}$ & $\begin{array}{l}3.36 \pm \\
0.26 \mathrm{a}\end{array}$ \\
\hline $10 \% \mathrm{FB}$ & $\begin{array}{l}4.13 \pm \\
0.29 \mathrm{~b}\end{array}$ & $\begin{array}{l}4.67 \pm \\
0.38 \mathrm{~b}\end{array}$ & $\begin{array}{l}4.73 \pm \\
0.52 \mathrm{~b}\end{array}$ & $\begin{array}{l}4,51 \pm \\
0.46 \mathrm{~b}\end{array}$ & $\begin{array}{c}3.48 \pm \\
0.30 \mathrm{~b}-\mathrm{d}\end{array}$ & $\begin{array}{r}3.99 \pm \\
0.25 \mathrm{ab}\end{array}$ & $\begin{array}{c}3,58 \pm \\
0.38 \mathrm{bcd}\end{array}$ & $\begin{array}{c}3.69 \pm \\
0.37 \mathrm{a}\end{array}$ & $\begin{array}{c}3.13 \pm \\
0.33 \mathrm{a}-\mathrm{c}\end{array}$ & $\begin{array}{c}3.21 \pm \\
0.29 \mathrm{a}-\mathrm{c}\end{array}$ & $\begin{array}{c}2.89 \pm \\
0.42 \mathrm{~b}-\mathrm{d}\end{array}$ & $\begin{array}{l}3,08 \pm \\
0.35 \mathrm{~b}\end{array}$ \\
\hline $20 \% \mathrm{FB}$ & $\begin{array}{c}0.03 \pm \\
0.21 \mathrm{a}\end{array}$ & $\begin{array}{l}4,52 \pm \\
0.50 \mathrm{~b}\end{array}$ & $\begin{array}{r}4,41 \pm \\
031 \mathrm{~b}\end{array}$ & $\begin{array}{c}4.98 \pm \\
0.84 \mathrm{a}\end{array}$ & $\begin{array}{l}3,05 \pm \\
0.36 \mathrm{~d}\end{array}$ & $\begin{array}{l}3.36 \pm \\
0.42 \mathrm{~d}\end{array}$ & $\begin{array}{c}4.41 \pm \\
0.31 \mathrm{~b}-\mathrm{d}\end{array}$ & $\begin{array}{c}3.28 \pm \\
0.38 \mathrm{~b}\end{array}$ & $\begin{array}{c}2.61 \pm \\
0.10 \mathrm{~d}\end{array}$ & $\begin{array}{c}2.84 \pm \\
0.15 \mathrm{c}\end{array}$ & $\begin{array}{c}2.92 \pm \\
0.34 b-d\end{array}$ & $\begin{array}{l}2.79 \pm \\
0.24 \mathrm{c}\end{array}$ \\
\hline $\begin{array}{c}\text { Average } \\
\text { SWB }\end{array}$ & $\begin{array}{c}4.96 \pm \\
0.85 \mathrm{a} \\
\end{array}$ & $\begin{array}{l}4,54 \pm \\
0.36 \mathrm{~b}\end{array}$ & $\begin{array}{l}4,57 \pm \\
0.43 \mathrm{~b}\end{array}$ & & $\begin{array}{c}3.44 \pm \\
0.41 \mathrm{a}\end{array}$ & $\begin{array}{c}3.74 \pm \\
0.46 \mathrm{a}\end{array}$ & $\begin{array}{c}3.76 \pm \\
0.55 \mathrm{a}\end{array}$ & & $\begin{array}{c}2.98 \pm \\
0.33 \mathrm{a}\end{array}$ & $\begin{array}{l}3.20 \pm \\
0.38 \mathrm{a}\end{array}$ & $\begin{array}{c}3,04 \pm \\
0.37 \mathrm{a} \\
\end{array}$ & \\
\hline
\end{tabular}

The similar or common letters on the averages in the same category mean that there are no significant differences between these averages, according to the Duncan test.

The different letters on the averages within the same character have significant differences $(\mathrm{P} \leq 0.05)$ among those averages, according to the Duncan test. 
Mesopotamia J. of Agric.

Vol. (47) No. (2) 2019
ISSN: 2224 - 9796 (Online)

ISSN: 1815 - 316 X (Print)

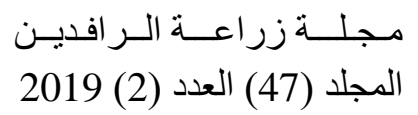

Table (5): Effect of SWB and FB minor treatments on percentage of egg production at $1^{\text {st }}, 2^{\text {nd }}$ and $3^{\text {rd }}$ four weeks of production.

\begin{tabular}{|c|c|c|c|c|c|c|c|c|c|c|c|c|}
\hline & \multicolumn{4}{|c|}{$1-4$ weeks } & \multicolumn{4}{|c|}{5 - 8 weeks } & \multicolumn{4}{|c|}{$9-12$ weeks } \\
\hline & $\begin{array}{c}0 \% \\
\text { SWB }\end{array}$ & $\begin{array}{l}10 \% \\
\text { SWB }\end{array}$ & $\begin{array}{l}20 \% \\
\text { SWB }\end{array}$ & $\begin{array}{c}\text { Average } \\
\text { FB }\end{array}$ & $\begin{array}{c}0 \% \\
\text { SWB }\end{array}$ & $\begin{array}{l}10 \% \\
\text { SWB }\end{array}$ & $\begin{array}{l}20 \% \\
\text { SWB }\end{array}$ & $\begin{array}{c}\text { Average } \\
\text { FB }\end{array}$ & $\begin{array}{c}0 \% \\
\text { SWB }\end{array}$ & $\begin{array}{l}10 \% \\
\text { SWB }\end{array}$ & $\begin{array}{l}20 \% \\
\text { SWB }\end{array}$ & $\begin{array}{c}\text { Average } \\
\text { FB }\end{array}$ \\
\hline $0 \% \mathrm{FB}$ & $\begin{array}{c}56.87 \pm \\
3.55 \mathrm{c} \\
\end{array}$ & $\begin{array}{l}66.58 \pm \\
0.45 \mathrm{ab}\end{array}$ & $\begin{array}{l}61.13 \pm \\
9.48 \mathrm{a}-\mathrm{c}\end{array}$ & $\begin{array}{c}61.52 \pm \\
6.72 \mathrm{a} \\
\end{array}$ & $79.40 \pm 0.65 \mathrm{a}$ & $\begin{array}{r}77.28 \pm \\
6.60 \mathrm{a} \\
\end{array}$ & $\begin{array}{c}79.73 \pm \\
6.25 \mathrm{a} \\
\end{array}$ & $\begin{array}{r}78.00 \pm \\
4.89 \mathrm{a} \\
\end{array}$ & $\begin{array}{c}81.90 \pm \\
0.65 \mathrm{c} \\
\end{array}$ & $\begin{array}{c}76.92 \pm \\
7.99 \mathrm{~d}\end{array}$ & $\begin{array}{l}89.23 \pm \\
6.84 \mathrm{a}-\mathrm{c}\end{array}$ & $\begin{array}{c}82.68 \pm \\
7.63 \mathrm{~b}\end{array}$ \\
\hline $10 \% \mathrm{FB}$ & $\begin{array}{r}67.43 \pm \\
1.71 \mathrm{a} \\
\end{array}$ & $\begin{array}{l}63.58 \pm \\
7.27 \mathrm{a}-\mathrm{c}\end{array}$ & $\begin{array}{l}62.43 \pm \\
5.83 \mathrm{a}-\mathrm{c} \\
\end{array}$ & $\begin{array}{c}64.48 \pm \\
5.43 \mathrm{a} \\
\end{array}$ & $83.13 \pm 6.34 \mathrm{a}$ & $\begin{array}{c}78.93 \pm \\
7.24 \mathrm{a} \\
\end{array}$ & $\begin{array}{c}82.06 \pm \\
3.24 \mathrm{a} \\
\end{array}$ & $\begin{array}{r}81.375 \pm \\
5.62 \mathrm{a} \\
\end{array}$ & $\begin{array}{l}88.13 \pm \\
3.38 \mathrm{a}-\mathrm{c} \\
\end{array}$ & $\begin{array}{c}84.68 \pm \\
7.20 \mathrm{~b}-\mathrm{d} \\
\end{array}$ & $\begin{array}{c}91.28 \pm \\
1.65 \mathrm{ab} \\
\end{array}$ & $\begin{array}{c}88.03 \pm \\
5.09 \mathrm{a} \\
\end{array}$ \\
\hline $20 \% \mathrm{FB}$ & $\begin{array}{r}41.73 \pm \\
3.65 \mathrm{~d} \\
\end{array}$ & $\begin{array}{l}59,30 \pm \\
2.65 \mathrm{bc}\end{array}$ & $\begin{array}{l}63.88 \pm \\
0.99 \mathrm{a}-\mathrm{c}\end{array}$ & $54.97 \pm 10.30 \mathrm{~b}$ & $81.63 \pm 4.25 \mathrm{a}$ & $\begin{array}{c}77.89 \pm \\
3.35 \mathrm{a} \\
\end{array}$ & $\begin{array}{c}84.00 \pm \\
3.85 \mathrm{a} \\
\end{array}$ & $\begin{array}{c}81.167 \pm \\
4.35 \mathrm{a} \\
\end{array}$ & $\begin{array}{l}89.40 \pm \\
7.56 \mathrm{a}-\mathrm{c} \\
\end{array}$ & $\begin{array}{c}81.93 \pm \\
6.59 \mathrm{c} \\
\end{array}$ & $\begin{array}{c}94.10 \pm \\
2.41 \mathrm{a} \\
\end{array}$ & $\begin{array}{c}88.48 \pm \\
7.51 \mathrm{a} \\
\end{array}$ \\
\hline $\begin{array}{l}\text { Average } \\
S \text { W B }\end{array}$ & $\begin{array}{lll}55.34 & \pm \\
11.39 & 6\end{array}$ & $\begin{array}{l}63.15 \pm \\
5.11 \quad a\end{array}$ & $\begin{array}{l}62.48 \pm \\
5.95\end{array}$ & & $\begin{array}{ccccc}8 & 1 & .3 & 8 & \pm \\
4 & . & 3 & 1 & \mathrm{a}\end{array}$ & $\begin{array}{l}78.03 \pm \\
5.45 \mathrm{a}\end{array}$ & $\begin{array}{l}81.93 \pm \\
4.57 \mathrm{a}\end{array}$ & & $\begin{array}{l}86.48 \pm \\
5.53 \quad b\end{array}$ & $\begin{array}{l}81.18 \pm \\
7.39 \quad c\end{array}$ & $\begin{array}{l}91.53 \pm \\
4.41\end{array}$ & \\
\hline
\end{tabular}

The same or common letters on the averages within one adjective mean that there are no significant differences between these averages, According to the Duncan test.

The different letters on the averages within the same character have significant differences $(\mathrm{P} \leq 0,05)$ among these averages, according to the Duncan test. 
Mesopotamia J. of Agric.

Vol. (47) No. (2) 2019
ISSN: 2224 - 9796 (Online)

ISSN: 1815 - 316 X (Print)

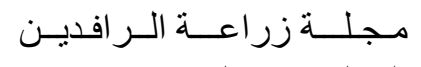

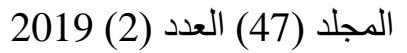

Table (6): Effect of SWB and FB minor treatments on fertilized eggs percentage at $1^{\text {st }}, 2^{\text {nd }}$ and $3^{\text {rd }}$ four weeks of production.

\begin{tabular}{|c|c|c|c|c|c|c|c|c|c|c|c|c|}
\hline & \multicolumn{4}{|c|}{ 1-4 weeks } & \multicolumn{4}{|c|}{5 - 8 weeks } & \multicolumn{4}{|c|}{$9-12$ weeks } \\
\hline & $\begin{array}{c}0 \% \\
\text { SWB }\end{array}$ & $\begin{array}{l}10 \% \\
\text { SWB }\end{array}$ & $\begin{array}{l}20 \% \\
\text { SWB }\end{array}$ & $\begin{array}{c}\text { Average } \\
\text { FB }\end{array}$ & $\begin{array}{c}0 \% \\
\text { SWB }\end{array}$ & $\begin{array}{l}10 \% \\
\text { SWB }\end{array}$ & $\begin{array}{l}20 \% \\
\text { SWB }\end{array}$ & $\begin{array}{c}\text { Average } \\
\text { FB }\end{array}$ & $\begin{array}{c}0 \% \\
\text { SWB }\end{array}$ & $\begin{array}{l}10 \% \\
\text { SWB }\end{array}$ & $\begin{array}{l}20 \% \\
\text { SWB }\end{array}$ & $\begin{array}{c}\text { Average } \\
\text { FB }\end{array}$ \\
\hline $0 \% \mathrm{FB}$ & $\begin{array}{l}81.70 \pm \\
12.25 \mathrm{a}\end{array}$ & $\begin{array}{c}87.77 \pm 1 \\
1.01 \mathrm{a} \\
\end{array}$ & $\begin{array}{c}89.98 \pm \\
4.71 \mathrm{a} \\
\end{array}$ & $\begin{array}{c}86,50 \pm \\
9.67 \mathrm{a} \\
\end{array}$ & $\begin{array}{r}96.66 \pm \\
2.74 \mathrm{a} \\
\end{array}$ & $\begin{array}{c}95,50 \pm \\
3.18 \mathrm{a}\end{array}$ & $\begin{array}{l}92.10 \pm \\
4.12 \mathrm{ab}\end{array}$ & $\begin{array}{c}94.76 \pm \\
3.68 \mathrm{a} \\
\end{array}$ & $\begin{array}{l}95,70 \pm \\
0.57 \mathrm{ab}\end{array}$ & $\begin{array}{c}98.80 \pm \\
0.85 \mathrm{a} \\
\end{array}$ & $\begin{array}{l}94.98 \pm \\
1.25 \mathrm{AB}\end{array}$ & $\begin{array}{r}96,50 \pm \\
1.93 \mathrm{a}\end{array}$ \\
\hline $10 \% \mathrm{FB}$ & $\begin{array}{c}81.15 \pm \\
9.83 \mathrm{a}\end{array}$ & $\begin{array}{c}84.43 \pm \\
8.32 \mathrm{a}\end{array}$ & $\begin{array}{c}79,98 \pm \\
7,22 \mathrm{a}\end{array}$ & $\begin{array}{c}81.85 \pm \\
7.96 \mathrm{a}\end{array}$ & $\begin{array}{c}96.68 \pm \\
2.69 \mathrm{a}\end{array}$ & $\begin{array}{c}93,28 \pm \\
2.74 \mathrm{a}\end{array}$ & $\begin{array}{c}94.03 \pm \\
1.91 \mathrm{a}\end{array}$ & $\begin{array}{c}94.6 \pm 2 \\
714 \mathrm{a}\end{array}$ & $\begin{array}{l}96.60 \pm \\
2.49 \mathrm{AB}\end{array}$ & $\begin{array}{c}89.43 \pm \\
5.17 \mathrm{c}\end{array}$ & $\begin{array}{l}96.53 \pm \\
3.41 \mathrm{AB}\end{array}$ & $\begin{array}{r}94.18 \pm \\
4.95 \mathrm{a}\end{array}$ \\
\hline $20 \% \mathrm{FB}$ & $\begin{array}{c}82.20 \pm \\
6.86 \mathrm{a}\end{array}$ & $\begin{array}{l}76.68 \pm \\
13.59 \mathrm{a}\end{array}$ & $\begin{array}{l}76,68 \pm \\
50,55 \mathrm{a}\end{array}$ & $\begin{array}{l}78.52 \pm \\
13.63 \mathrm{a}\end{array}$ & $\begin{array}{c}93.23 \pm \\
2.57 \mathrm{a}\end{array}$ & $\begin{array}{c}95,50 \pm \\
1.70 \mathrm{a}\end{array}$ & $\begin{array}{c}88.28 \pm \\
4.09 \mathrm{~b}\end{array}$ & $\begin{array}{c}92.33 \pm \\
4.13 \mathrm{a}\end{array}$ & $\begin{array}{c}92.63 \pm \\
3.89 \mathrm{~b}\end{array}$ & $\begin{array}{l}95.10 \pm \\
1.96 \mathrm{ab}\end{array}$ & $\begin{array}{l}94.20 \pm \\
5.10 \mathrm{a}-\mathrm{c}\end{array}$ & $\begin{array}{r}93.98 \pm \\
3.66 \mathrm{a}\end{array}$ \\
\hline $\begin{array}{c}\text { Average } \\
\text { SWB }\end{array}$ & $\begin{array}{c}81.68 \pm \\
8.96 \mathrm{a}\end{array}$ & $\begin{array}{l}82.96 \pm \\
11.22 \mathrm{a}\end{array}$ & $\begin{array}{l}82.21 \pm \\
13.05 \mathrm{a}\end{array}$ & & $\begin{array}{c}95.52 \pm \\
2.95 \mathrm{a}\end{array}$ & $\begin{array}{c}94.76 \pm \\
2.61 \mathrm{a}\end{array}$ & $\begin{array}{c}91.47 \pm \\
4.05 \mathrm{~b}\end{array}$ & & $\begin{array}{c}94.98 \pm \\
3.01 \mathrm{a}\end{array}$ & $\begin{array}{c}94.44 \pm \\
4.97 \mathrm{a}\end{array}$ & $\begin{array}{c}95.23 \pm \\
3.42 \mathrm{a}\end{array}$ & \\
\hline
\end{tabular}

The similar or common letters on the averages in the same category mean that there are no significant differences between these averages, according to the Duncan test.

The different letters on the averages within the same character have significant differences $(\mathrm{P} \leq 0,05)$ among these averages, according to the Duncan test. 
Mesopotamia J. of Agric.

Vol. (47) No. (2) 2019
ISSN: 2224 - 9796 (Online)

ISSN: 1815 - 316 X (Print)

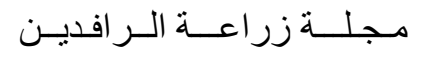

المجلد (47) العدد (2) 2019

Table (7): Effect of SWB and FB minor treatments on egg hatch percentage at $1^{\text {st }}, 2^{\text {nd }}$ and $3^{\text {rd }}$ four weeks of production.

\begin{tabular}{|c|c|c|c|c|c|c|c|c|c|c|c|c|}
\hline & \multicolumn{4}{|c|}{ 1-4 weeks } & \multicolumn{4}{|c|}{5 - 8 weeks } & \multicolumn{4}{|c|}{$9-12$ weeks } \\
\hline & $\begin{array}{c}0 \% \\
\text { SWB }\end{array}$ & $\begin{array}{l}10 \% \\
\text { SWB }\end{array}$ & $\begin{array}{l}20 \% \\
\text { SWB }\end{array}$ & $\begin{array}{c}\text { Average } \\
\text { FB }\end{array}$ & $\begin{array}{c}0 \% \\
\text { SWB }\end{array}$ & $\begin{array}{l}10 \% \\
\text { SWB }\end{array}$ & $\begin{array}{l}20 \% \\
\text { SWB }\end{array}$ & $\begin{array}{c}\text { Average } \\
\text { FB }\end{array}$ & $\begin{array}{c}0 \% \\
\text { SWB }\end{array}$ & $\begin{array}{l}10 \% \\
\text { SWB }\end{array}$ & $\begin{array}{l}20 \% \\
\text { SWB }\end{array}$ & $\begin{array}{c}\text { Average } \\
\text { FB }\end{array}$ \\
\hline $0 \% \mathrm{FB}$ & $\begin{array}{c}51.67 \pm \\
1.35 \mathrm{~b}\end{array}$ & $\begin{array}{l}60.00 \pm \\
8.16 \mathrm{a}-\mathrm{c}\end{array}$ & $\begin{array}{c}67.78 \pm \\
4.15 \mathrm{a} \\
\end{array}$ & $\begin{array}{c}59.81 \pm \\
8.40 \mathrm{a} \\
\end{array}$ & $\begin{array}{l}86.10 \pm \\
5.55 \mathrm{ab}\end{array}$ & $\begin{array}{c}86,50 \pm \\
2.94 \mathrm{a} \\
\end{array}$ & $\begin{array}{l}79.60 \pm \\
2.22 \mathrm{a}-\mathrm{c}\end{array}$ & $\begin{array}{c}84.07 \pm \\
4.80 \mathrm{a} \\
\end{array}$ & $\begin{array}{c}70.70 \pm \\
0.57 \mathrm{~b}\end{array}$ & $\begin{array}{c}76.58 \pm \\
8,28 \mathrm{~b}\end{array}$ & $\begin{array}{c}83.18 \pm \\
4.33 \mathrm{a}\end{array}$ & $\begin{array}{r}76.82 \pm \\
7.23 \mathrm{a}\end{array}$ \\
\hline $10 \% \mathrm{FB}$ & $\begin{array}{l}45.45 \pm \\
3.16 \mathrm{a}-\mathrm{c}\end{array}$ & $\begin{array}{l}64.48 \pm \\
3.16 \mathrm{ab}\end{array}$ & $\begin{array}{l}54.43 \pm \\
1.60 \mathrm{a}-\mathrm{c} \\
\end{array}$ & $\begin{array}{c}57.78 \pm \\
5.53 \mathrm{a} \\
\end{array}$ & $\begin{array}{c}77.63 \pm \\
8.13 \mathrm{~b} \\
\end{array}$ & $\begin{array}{l}82.08 \pm \\
2.92 \mathrm{a}-\mathrm{c}\end{array}$ & $\begin{array}{l}82.18 \pm \\
3.90 \mathrm{a}-\mathrm{c}\end{array}$ & $\begin{array}{c}80.63 \pm \\
4.80 \mathrm{a} \\
\end{array}$ & $\begin{array}{l}76.53 \pm \\
4.01 \mathrm{ab}\end{array}$ & $\begin{array}{l}75.43 \pm \\
9.32 \mathrm{ab}\end{array}$ & $\begin{array}{c}72.40 \pm \\
7.24 \mathrm{~b} \\
\end{array}$ & $\begin{array}{r}74.78 \pm \\
6.76 \mathrm{a} \\
\end{array}$ \\
\hline $20 \% \mathrm{FB}$ & $\begin{array}{l}46,68 \pm \\
15,13 \mathrm{c}\end{array}$ & $\begin{array}{l}58.90 \pm 1 \\
5.93 \mathrm{a}-\mathrm{c}\end{array}$ & $\begin{array}{l}52.23 \pm \\
11.01 \mathrm{~b}\end{array}$ & $\begin{array}{l}52.60 \pm \\
13.85 \mathrm{a}\end{array}$ & $\begin{array}{l}78.43 \pm \\
8.33 \mathrm{a}-\mathrm{c}\end{array}$ & $\begin{array}{c}86.53 \pm \\
0.24 \mathrm{a}\end{array}$ & $\begin{array}{c}74.03 \pm \\
6.97 \mathrm{c}\end{array}$ & $\begin{array}{c}79.66 \pm \\
5.42 \mathrm{a}\end{array}$ & $\begin{array}{c}63.48 \pm \\
4.66 \mathrm{c}\end{array}$ & $\begin{array}{l}73.83 \pm \\
8.18 \mathrm{ab}\end{array}$ & $\begin{array}{l}78.33 \pm \\
6.56 \mathrm{ab}\end{array}$ & $\begin{array}{c}71.88 \pm \\
8.83 \mathrm{a}\end{array}$ \\
\hline $\begin{array}{c}\text { Average } \\
\text { SWB }\end{array}$ & $\begin{array}{c}50.93 \pm \\
8.77 \mathrm{~b}\end{array}$ & $\begin{array}{c}61.13 \pm \\
9.82 \mathrm{a} \\
\end{array}$ & $\begin{array}{l}58.14 \pm \\
9.49 \mathrm{ab}\end{array}$ & & $\begin{array}{l}80,72 \pm \\
80,72 \mathrm{ab}\end{array}$ & $\begin{array}{c}85.03 \pm \\
3.08 \mathrm{a}\end{array}$ & $\begin{array}{c}78.60 \pm \\
5.60 \mathrm{~b}\end{array}$ & & $\begin{array}{c}70.23 \pm \\
6.44 \mathrm{~b}\end{array}$ & $\begin{array}{l}75.28 \pm \\
7.87 \mathrm{ab}\end{array}$ & $\begin{array}{c}77.97 \pm \\
7.23 \mathrm{a} \\
\end{array}$ & \\
\hline
\end{tabular}

The similar or common letters on the averages in the same category mean that there are no significant differences between these averages, according to the Duncan test.

The different letters on the averages within the same character have significant differences $(\mathrm{P} \leq 0.05)$ among these averages, according to the Duncan test 


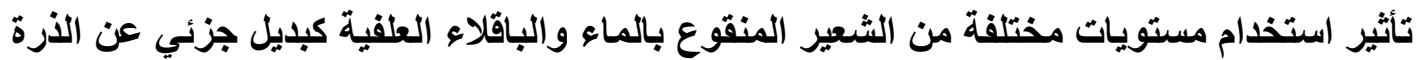

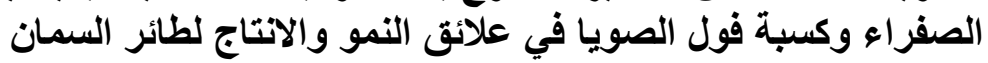

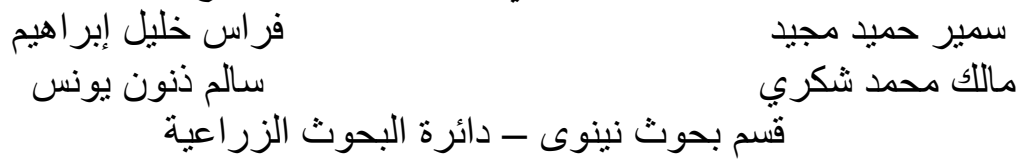

\section{الخلاصة}

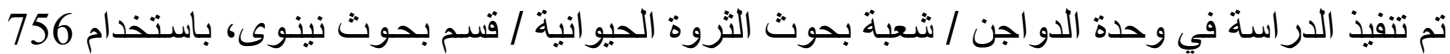

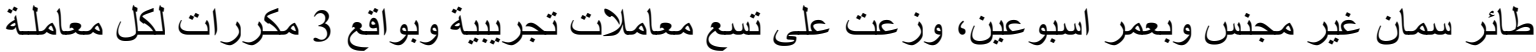

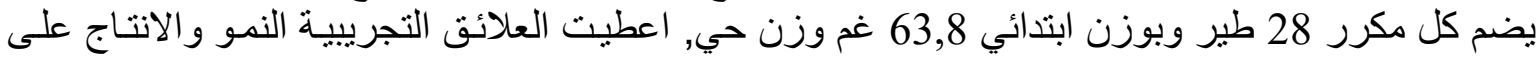

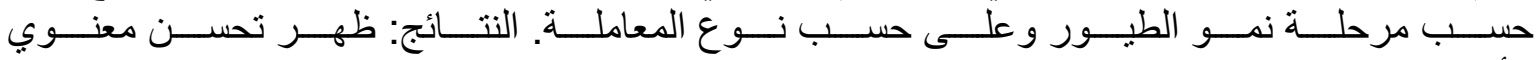

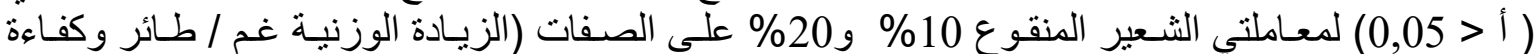

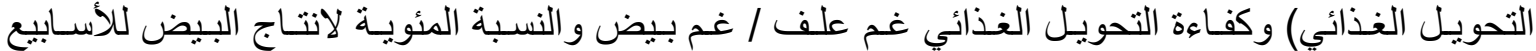

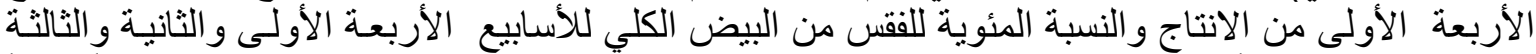

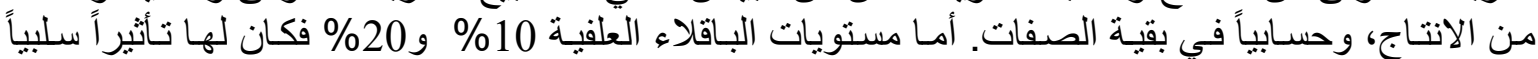
ومعنوياً ( أ > 0,05) على (الزيادة الوزنية غم / طائر وكفاءة التحويل الغذائي) عند عمر 3.

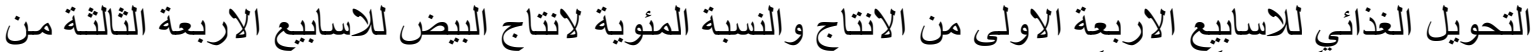

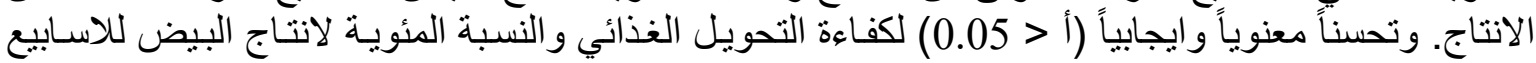
الاربعة الثالثة من الانتاج.

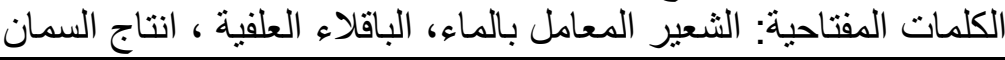

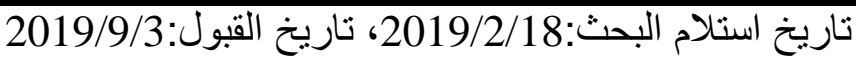

\section{REFERENCES}

Abdul-Abass , M. H. and A. H. Areaaer (2014). Effect of using chemically treated vicia faba bean in the diet in broiler carcass properties. The Iraqi Journal of Agricultural Sciences - 45(4)(Special Issue): 400-408.

Abdul-Abass, M.H. and R.I. AL-Mjamaii (2007). Use germination as a mean to improve the nutritional value of broad bean used in broiler diet. Iraqi Poultry Sciences 2(3):80-93.

Ahmed , S. M. (2011). Effect of $\beta$-glucanases addition, hulling and water soaking for the barley on performance of broiler chickens. Journal of Koya University 20:1-11.

Al- Rawi , K. M. and A. M. Khalaf-Allah. (2000). Design and Analysis of Agricultural Experimental, Mosul University, Iraq.

Al-Kaisey, M. T.; M. A. Mohammad ; S. M. Abou-Tubik ; M. K. Al-Fadhli and M. M. Abdul-Abass. (2007). Effect of germination in improving the feed value of two local barley cultivars in broiler chick diets. Mesopotamia Journal of Agriculture 35 (2): 75-83.

Bosco, A. D. ; S. Ruggeri ; S. Mattioli; C. Mugnai; F. Sirri and C. Castellini . (2013). Effect of (Faba Bean Vicia Faba Var, Minor) inclusion in starter and growing diet on performance, carcass and meat characteristics of organic slow- growing chickens. Italian Journal of Animal Science 12(4): 472-478. 
Garci’a , M.; R. La'zaro ; M. A. Latorre; M. I. Gracia; and G. G. Mateos . (2008). Influence of enzyme supplementation and heat processing of barley on digestive traits and productive performance of broilers. Poultry Science. 87(5):940-948.

Jacob, J. P. and A. J. Pescatore (2012). Using barley in poultry diets - A Review. The Journal of Applied Poultry Research 21 :915-940.

Kianfar, R. ; H. Moravej; M. Shivazad and M. Taghinejad-Roudbaneh (2013). Effect of enzyme addition, germination, and fermentation on the nutritive value of barley for growing Japanese quails. Journal of Animal and Feed Sciences. 22:165-171.

Koivunen, E. ; P. Tuunainen ; E. Valkonen; L. Rossow and J. Valaja (2014). Use of faba (Vicia faba) in diets of laying hens. Agricutural and Food Science. 23 : 165-172.

Mortazavi, F. and M. Afsharmanesh (2017). Evaluation the effect of feeding method (dry-wet) on Japanese quail performance. Journal of Novel Applied Sciences. 6 (1): 1-6.

Rasteh, M. R. ; B. Dastar; M. S. Shargh; S. Zerehdaran and O. Ashayerizadeh (2016). Effect of different levels of germinated barley on performance and egg quality in laying hen. International Journal of Advanced Biological and Biomedical Research. 4 (2): 117-125.

Anonymous (2002). Statistical Analysis System. SAS institute Inc. Release 6.12 Tsozo, North Carolina state University of Cary, NC, U.S.A.

Senkoylu, N. ; H. Akyurek and H. E. Samli (2004). Implications of $\beta$-glucanase and pentosanase enzymes in low-energy low-protein barley and wheat based broiler diets. Czech Journal of Animal Science 49 (3): 108-114.

Svihus, B.; R. K. Newman ; C. W. Newman and O. I. Selmer (1997). Changes in extract viscosity, amino acid content, and soluble and insoluble $\beta$-glucan and dietary fibre content of barley during different high moisture storage conditions. Animal Feed Science and Technology. 64, 257-272. 